\title{
Sistem Informasi Kasir pada Restoran Siap Saji FoodPanda Berbasis Desktop
}

\author{
Jafar Shadiq ${ }^{1, *}$, Rayhan Wahyudin Ratu Lolly ${ }^{1}$ \\ ${ }^{1}$ Rekayasa Perangkat Lunak; Universitas Bina Insani; Jl.Siliwangi No.6 Rawa Panjang Rawa \\ Lumbu Bekasi, (021) 82400924; e-mail: jafarshadia@binainsani.ac.id, \\ rayhan.wahyudin21@gmail.com \\ * Korespondensi: e-mail: jafarshadia@binainsani.ac.id
}

Diterima: 16 Desember 2020; Review: 22 Desember 2020; Disetujui: 29 Desember 2020

Cara sitasi: Shadiq J, Lolly RWR. 2020. Perancangan Sistem Informasi Kasir pada Restoran Siap Saji FoodPanda Berbasis Desktop. Information Management for Educators and Professionals. Vol 5 (1): 85 - 94.

\begin{abstract}
Abstrak: Toko FoodPanda merupakan toko penjual makan dan minuman khas Tiongkok yang berlokasi dibekasi. Toko FoodPanda didirikan oleh seorang wirausaha muda dalam kegiatan bisnisnya adalah menjualkan berbagai jenis makanan khas Tiongkok dengan cita rasa dan sari rempah-rempah Indonesia. Toko Foodpanda ini tergolong sebuah perusahaan dibidang makanan yang semua proses pengolahan datanya dari data master makanan, minuman, pelanggan, karyawan, laporan hingga transaksi pembelian dan pemesanan. Semua itu diolah oleh perusahaan tersebut dengan tumpukan kertas dan setiap transaksi berbeda dokumentasi. Tentu ini akan memakan banyak tempat bila FoodPanda tetap berjalan seiring waktu. Perancangan sistem informasi berupa aplikasi yang dibutuhkan oleh Toko FoodPanda untuk menjalankan bisnisnya jauh lebih baik tanpa terjadi kesalahan terutama dalam pelaporannya saat pembayaran dikasir. Pembuatan aplikasi menggunakan metode waterfall. Dengan adanya sistem aplikasi kasir akan membantu Toko FoodPanda dalam menjalankaan bisnisnya tanpa ada kesalahan atau masalah baik dari internal atau eksternal.
\end{abstract}

Kata kunci: aplikasi, foodpanda, toko, kasir, waterfall.

Abstract: The FoodPanda shop is a Chinese food and beverage shop located in Bekasi. The FoodPanda shop was founded by a young entrepreneur whose business activity is to sell various types of Chinese specialties with the flavors and extracts of Indonesian spices. This Foodpanda shop is classified as a company in the food sector where all data processing processes are from master data of food, beverages, customers, employees, reports to purchase and order transactions. All of that is processed by the company with piles of paper and each transaction has different documentation. Of course this will take up a lot of space if FoodPanda continues to run over time. The design of an information system in the form of an application needed by the FoodPanda store to run its business is much better without any errors, especially in reporting when payments are cashed. Making applications using the waterfall method. With the cashier application system, it will help the FoodPanda Store in running its business without any errors or problems from both internal and external.

Keywords: Application, Cashier, FoodPanda, waterfall, shop.

\section{Pendahuluan}

Pada era modernisasi saat ini mayoritas manusia diberikan tekanan untuk harus bisa mengerjakan kewajiban dari segala pekerjaan dengan benar, cepat, tepat serta akurat, sehingga dalam menunjang mayoritas manusia saat menuntaskan segala pekerjaannya membutuhkan sebuah perangkat teknologi canggih seperti komputer dan sistem informasi aplikasi sesuai pada kebutuhan pekerjaannya di masing - masing bagian tertentu. 
Sistem informasi atau biasa disebut aplikasi adalah sebuah prase yang sangat krusial tentunya dan diharuskan ada dalam suatu perusahaan atau kegiatan usaha maupun organisasi, mengapa demikian, karena aplikasi yang sesuai dengan pekerjaan dapat membuat dan merekap sebuah informasi usaha yang benar, cepat dan sesuai yang diharapkan, kemudian dari pada itu juga aplikasi dapat membantu dan mempermudah pada saat proses data yaitu proses pengolahan informasi usaha yang sedang berjalan, seperti: rekap data transaksi, penginputan data dan pengecekkan data dan hal-hal lainnya baik dari sebuah inputan data transaksi menuju kepada proses pengolahan data sampai dengan hasil output yang diinginkan.

Perusahaan akan kebutuhan kepada sebuah informasi yang lebih cepat, akurat, mudah dan sesuai apa yang diinginkan sehingga membuat banyak perusahaan atau organisasi banyak melakukan kegiatan usahanya secara terkomputerisasi dalam arti seua kegiatan usahanya dapat terekam secara otomatis dalam komputer dengan alasan lebih menghemat soal waktu, mengurangi cacat atau resiko data loss pada usahanya, mempermudah saat melaukan pengolahan data yang sesuai dan tidak lagi menyediakan seperti ruang arsip yang berukuran besar di dalam perusahaan maupun diluar, karena jika perusahaan atau organisasi unit usaha melaraskan pada sistem yang bersifat manual dalam arti yaitu proses kegiatan usaha baik input proses dan output menggunakan secarik kertas ataubun bahan lain tentunya ini akan berdampak pada banyak resiko yang terjadi seperti crash data, menghabiskan lebih banyak waktu untuk mendapatkan memproses banyaknya informasi selain itu juga informasi yang didapt akan tidak akurat jadi tidak sesuai denga napa yang diharapkan.

Dalam hal ini terdapat beberapa toko dalam usaha yang diberikan dan disediakan dalam bentuk barang ataupun dalam bentuk jasa dan semua itu saling mengejar tertinggalannya untuk mengimplementasikan sebuah aplikasi tepat guna dalam merubah dari tumpukan banyak kertas menjadi sifat paper less untuk siap bersaing secara sehat dengan toko-toko sejenis lainnya.

Salah satu toko dibekasi yaitu toko FoodPanda. Toko FoodPanda didirikan oleh seorang wirausaha muda dalam kegiatan bisnisnya adalah menjualkan berbagai jenis makanan khas Tiongkok dengan cita rasa dan sari rempah-rempah Indonesia. Toko Foodpanda ini tergolong sebuah perusahaan dibidang makanan yang semua proses pengolahan datanya dari data master makanan, minuman, pelanggan, karyawan, laporan hingga transaksi pembelian dan pemesanan. Semua itu diolah oleh perusahaan tersebut dengan tumpukan kertas dan setiap transaksi berbeda dokumentasi. Tentu ini akan memakan banyak tempat bila FoodPanda tetap berjalan seiring waktu.

Pengolahan semua data pada toko tersebut direkap dan dodokumentasikan setiap seminggu sekali dan membutuhkan waktu kurang lbih tiga hari kerja bahkan hari liburpun menjadi tumbal bilamana saat pendokumentasian terjadi kejanggalan seperti informasi transaksi ada yang hilang, rusak bahkan bisa juga terjadi kecurangan dari karyawannnya yang ingin meraup keuntungan degan cara yang sangat menrugikan perusahaan.

Dari berbagai hal-hal tersebut yang dialami oleh Toko FoodPanda tersebut tentunya memiliki alasan tentang menerapkan sistem informasi yang masih berupa arsip kertas dan saat ini timbullnya kesadaran dari toko tersebut untuk beralih menggunakan sistem informasi berbasis teknologi komputer yang akan membawa toko FoodPanda mampu bersaing dengan lawan usahanya.

Dari uraian masalah diatas membuat ketertarikan dalam melakukan sebuah penelitian dan mencoba membuat sebuah peranangan sistem informasi dalam bentuk aplikasi yang dibutuhkan Toko FoodPanda agar semua kegiatan usahanya dapat berjalan dengan baik walaupun sekitarnya banyak pesaing.

Tujuan dari penilitian ini adalah membantu petugas toko dalam pengolahan data penjualan dengan membangun sebuah system informasi aplikasi kasir pada toko FoodPanda.

Manfaat yang diperoleh oleh Toko FoodPanda jika menerapkan aplikasi adalah akan sangat membantu dalam hal pengolahan data seperti transaksi-transaksi penjualan dan pelaporan data yang akan jauh lebih mudah dan hemat waktu serta terhindar dari kesalahan baik kesalahan internal maupun eksternal yang mungkin saja terjadi tanpa terduga dan juga akan memberikan nilai ke akuratan pada dokumentasi pelaporan yang telah ditetapkan sesuai dengan kebijakan perusahaan FoodPanda.

Perusahaan atau organisasi sangatlah membutuhkan sebuah sistem yang dapat menunjang semua kegiatan bisnisnya sehingga kinerjja perusahaan akan semakin lebih baik dengan perkembangan teknoloogi saat ini. Sistem adalah suatu jaringan kerja dari prosedur- 
prosedur yang saling berhubungan, berkumpul bersama- sama untuk melakukan suatu kegiatan atau untuk menyelesaikan suatu sasaran yang tertentu[1].

Informasi yang dibutuhkan oleh perusahaan bertujuan untuk memproses sebuah datadata yang terima oleh perusahaan atau organisasi yang nantinya akan digunakan dalam pencapaian target perusahaan selama melakukan kegiatan bisnis. Informasi juga merupakan sekumpulan data yang telah diproses dan digunakan saat perusahaan atau organisasi mengambil sebuah keputusan demi perusahaan mencapai tujuan dan kesejahteraan.

Sistem dan informasi yang telah diproses oleh sistem akan di distribusikan oleh perusahaan sehingga perusahaan memilki data informasi yang valid. Sistem Informasi adalah kumpulan elemen-elemen yang saling terhubung satu sama lain dalam bentu satu kesatuan untuk mengintegrasikan data, memproses data, dan menyimpan data serta mendistribusikan data informasi[2]. Database adalah kumpulan dari item data (file atau tabel) yang saling berhubungan satu dengan yang lainnya[3] yang diorganisasikan berdasarkan sebuah skema atau struktur tertentu, tersimpan dalam perangkat keras komputer, dan digunakan perangkat lunak untuk memanipulasinya[4].

Dalam penulisan jurnal ini penulis menggunakan beberapa referensi dari penulis lain yaitu diantaranya Sapto yang menuliskan tentang perancangan sebuah aplikasi Point of Sales berbasis web yang dibangun untuk mencatatkan semua transaksi penjualan dan untuk mengolah dan mengelola data pada klinik Spa Colony Amaranta. Metode Pengembangan dari sistem informasi menggunakan metode Waterfall dan menerapkan unified Modelling Language dalam perancangan proses bisnis sistem serta menggunakan bahasa pemrograman PHP dengan framework codeigneiter, hasil dari kegiatan penelitian yang dilakukan adalah perancangan sistem informasi seperti form pengolahan data master, form registrasi dan laporan[5].

\section{Metode Penelitian}

Pada bab ini diuraikan juga kerangka kerja penelitian (framework) yang digunakan dalam penyelesaian penelitian ini. Kerangka kerja ini merupakan tahap-tahap yang akan dilakukan dalam penyelesaian masalah yang akan dibahas. Adapun kerangka kerja dari penelitian ini dapat digambarkan pada gambar 1. berikut:

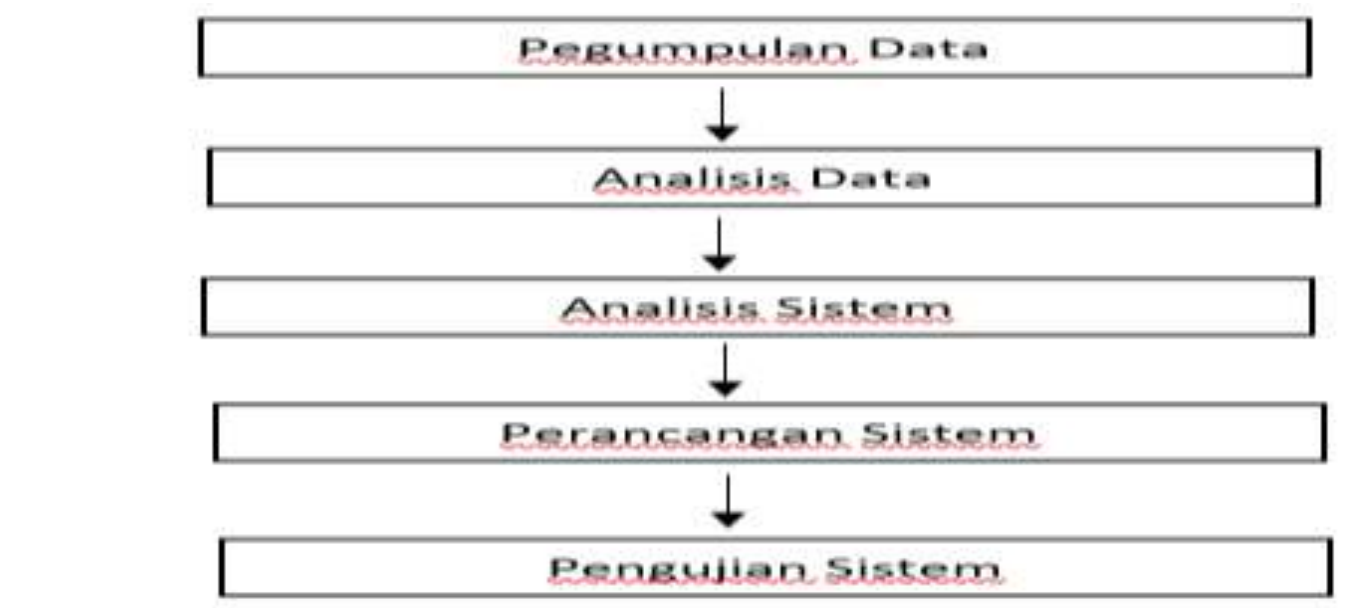

Sumber: Penelitian 2020

Gambar 1. Kerangka Pemikiran

Pada rangkaian sub-sub kerangka kerja digambar 1. pada peniltian ini selanjutnya dapat diuraikan sebagai berikut:

\section{Pengumpulan data}

Dalam metode penilitian ini di dahului oleh teknik pengumpulan data berdasarkan dari 3 jenis Teknik yaitu[6]:a. Pengamatan (observasi). Teknik pengumpulan data dengan mendatangi langsung kelapangan dalam hal ini adalah toko FoodPanda. b. Wawancara adalahTeknik pengumpulan data dengan mewawancarai langsung kepada pelaku bisnis[7] atau sumber informasi berdasarkan kepada pihak-pihak yang berkaitan dengan pelaku bisnis toko makanan 
khas Tiongkok dalam hal ini adalah Toko FoodPanda. c. Studi Pustaka. Teknik pengumpulan studi Pustaka dengan mengumpulkan dan menterjemahkan dari berbagai sumber referensi kajian ilmu yang serupa guna penelitian akan perancangan sistem informasi aplikasi kasir pada toko FoodPanda ini sesuai dengan maksud dari penelitian ini.

\section{Analsis Data}

Setelah tahap pengumpulan data dari berbagai sumber dan Teknik pengumpulannya selanjutnya adalah tahap analisis pada data yang telah tersedia. Analisis data ini memiliki tujuan yaitu dimana data yang sudah terkumpul kemudian dianalisis sesuai dengan apa yang dibutuhkan oleh toko FoodPanda pada saat penyelesaian peniltian ini supaya dengan data yang dibutuhkan tersebut penelitian ini dapat diproses dengan baik dan berkelanjutan terhadap analisis berikutnya.

\section{Analisis Sistem}

Tahap selanjutnya setelah dari tahap analisis data dimana data-data yang sudah terkumpul dan sudah dianalisiskan menjadi acuan terhadap sistem yang sedang berjalan pada Toko FoodPanda. Penjelesan pada tahap Analisis sistem ini memiliki arti atau gambaran seputar tentang alur proses sistem saat ini dan bertujuan agar lebih jelas mengetahui cara kerja sistem atau rancangan sistem yang sedang berjalan serta mendeskripsikan dari hasil temuan dan juga sebagai bahan evaluasi permasalahan yang saat ini telah terjadi dengan beberapa kebutuhan-kebutuhan yang diharapkan dapat diusulkan suatu perbaikan.

\section{Perancangan Sistem}

Pada tahap perancangan sistem ini membahas mengenai perancangan sistem informasi menggunakan model sistem yang akan menentukan rancangan dari input, process dan output dalam membangun aplikasi kasir penjualan pada FoodPanda dengan model waterfall. Metode air terjun atau metode waterfall ini merupakan siklus hidup klasik (classic life cycle), dimana hal ini menggambarkan pendekatan yang sistematis dan juga berurutan pada pengembangan perangkat lunak, dimulai dengan spesifikasikebutuhan pengguna lalu berlanjut melalui tahapantahapan perencanaan (planning), permodelan (modeling), konstruksi (construction), serta penyerahan sistem ke para pelanggan/pengguna (deployment), yang diakhiri dengan dukungan pada perangkat lunak lengkap yang dihasilkan[8]. Berikut tahapan dari metode waterfall:[9] a. Requirements analysis and definition berupa Layanan sistem, kendala, dan tujuan ditetapkan oleh hasil konsultasi dengan pengguna yang kemudian didefinisikan secara rinci dan berfungsi sebagai spesifikasi sistem. b. System and software design Tahapan perancangan sistem mengalokasikan kebutuhan-kebutuhan sistem baik perangkat keras maupun perangkat lunak dengan membentuk arsitektur sistem secara keseluruhan[10]. Perancangan perangkat lunak melibatkan identifikasi dan penggambaran abstraksi sistem dasar perangkat lunak dan hubungannya. c Implementation and unit testing Pada tahap ini, perancangan perangkat lunak direalisasikan sebagai serangkaian program atau unit program. Pengujian melibatkan verifikasi bahwa setiap unit memenuhi spesifikasinya. d. Integration and system testing Unit-unit individu program atau program digabung dan diuji sebagai sebuah sistem lengkap untuk memastikan apakah sesuai dengan kebutuhan perangkat lunak atau tidak. Setelah pengujian, perangkat lunak dapat dikirimkan ke customer. e. Operation and maintenance Biasanya (walaupun tidak selalu), tahapan ini merupakan tahapan yang paling panjang. Sistem dipasang dan digunakan secara nyata. Maintenance melibatkan pembetulan kesalahan yang tidak ditemukan pada tahapan-tahapan sebelumnya, meningkatkan implementasi dari unit sistem, dan meningkatkan layanan sistem sebagai kebutuhan baru.

\section{Implementasi Sistem}

Tahap implementasi berupa tahap perancangan sistem informasi yang dibangun dengan hasil data analisis dari toko FoodPanda yang tepat sehingga hasil dari implemetasi dapat sesuai dengan yang dibutuhkan pada toko makanan khas Tiongkok tersebut.

\section{Pengujian Sistem}

Di tahap pengujian pada peniltian ini menjadi hal yang terpenting setelah tahap implementasi telah selesai pada tahap ini hasil dari implemetasi sistem aplikasi kasir pada toko FoodPanda akan diuji guna memasikan terhadap semua fungsi yang telah dibangun apakah 
sudah memenuhi atau belum dan juga pada tahap ini bertujuan untuk menemukan sebuah kesalahan-kesalahn yang terjadi pada hasil rancang bangun sistem informasi aplikasi kasih penjualan pada toko FoodPanda tersebut. Metode yang digunakan dalam tahap pengujian sistem ini yaitu menggunakan metode Black Box Testing[11]. Apabila menemukan kesalahan dari apa yang sudah diimplementasikan akan terkoordinir lebih tepat sehingga semua fitur dapat berjalan dengan baik sesuai ddengan apa yang diinginkan.

\section{Hasil dan Pembahasan}

Pada bagian ini, dijelaskan hasil penelitian dan pada saat yang sama diberikan pembahasan yang komprehensif. Hasil dapat disajikan dalam angka, grafik, tabel dan lain-lain yang membuat pembaca memahami dengan mudah. Dalam bab ini berisikan terkait sesuatu yang diperlukan dalam peniltian ini yaitu melakukan analisis kebutuhan data perangkat lunak.

\section{Proses bisnis sistem}

Pada proses bisnis sistem yang saat ini berjalan pada toko FoodPanda dalam menangani berbagai permasalahan tertuma bagian kasir penjualan makanan. Proses utama pada Toko FoodPanda ini adalah proses pemesanan makanan sampai dengan pembuatan laporan perperiodeya yaitu: Tahap pemesanan, pelanggan dapat memilih makanan yang tersedia dibuku menu dengan banyak pilihan berdasarkan dari tingkat kesulitan dalam membuat makanan hingga harga yang dibebankan kepada pelanggan. Tahap pembayaran, pelanggan yang telah selesai menyantap hidangan yang sesui dengan pesanannya kemudian pelanggan menuju ke kasir untuk melakukan transaksi pemabyaran, kasir akan menanyakan menu makanan apa yang telah dibelinya dan jika pelanggan setuju denga napa yang disebutkan oleh kasir maka kasir akan menghitung jumlah makanan yang dibeli. Tahap pengembalian uang, setelah kasih menyebutkan kalkulasi harga yang harus dibayarkan oleh pelanggan kemudian pelanggan akan membayarnya baik uang yang dibayarkan sesuai dengan jumlah tagihan atau juga pelanggan memberikan uang lebih maka kasir akan mengembalikan sisa kelebihan dari pembayaran tersebut. Tahap pemberian bukti bayar, Kasir akan memberikan bukti bayar berupa kertas yang berisikan menu makanan yang dibeli oleh pelanggan dimana bukti bayar tersebut berisikan terkait menu apa saja yang telah dibeli oleh pelanggan dengan nominal setiap menu sampai dengan jumlah total dari tagihan hingga jumlah pembayaran yang pelanggan berikan. Tahap pelaporan, laporan yang ditagih oleh pemilik yaitu laporan penjualan harian, mingguan dan bulanan apakah sudah sesuai dengan jumlah pembelian makanan oleh pelanggan balance dengan jumlah pendapatkan dari proses penjualan makanan tersebut. Tahap pelaporan ini buat dalam bentuk buku laporan penjualan dengan isi dari jenis atau menu yang tersedia dan jumlah menu yang terjual kemudian dihitung sehingga pemilik dapat tau dari laporan tersebut.

\section{Analisis sistem usulan}

Pada analisis sistem yang diusulkan dalam penelitian ini kepada toko FoodPanda berawal dari input data pegawai toko hingga cetak laporan. Tahap input terbagi menjadi beberapa fitur yaitu, fitur input pegawai yang akan dijadikan pengguna sistem baik pegawai tersebut dijadikan menjadi kasir, admin, ataupun menjadi owner selain itu juga masih dalam tahap input master makanan dan minuman yang berisikan informasi data terkait nama makanan dan minuman serta harga yang ter generate langsung oleh kode dari setiap jenis-jenis tersebut. Tahap login aplikasi, pegawai akan memiliki beberapa akun dengan hak akses sesuai dengan bagian kerja masing-masing, kasir hanya dapat mengakses pembayaran saja, owner hanya dalat melihat hasil reporting dari jumlah penjualan yang sudah selesai berupa laporan yang dalat dilihat dari periode tanggal dan bulan sedangkan admin memilki hak akses penuh dalam manage software kasir toko FoodPanda baik dari pengembangan sistem, pengisian data pengguna, makanan minuman awal, dan menjaga performa dari perangka lunak tersebut. Setiap hak akses yang diberikan oleh admin merupakan struktur kerja sesuai dengan bidang masing-masing dan tidak bisa diganggu dengan user lain walaupun dengan devisi yang berbeda. Tahap transaksi yang dilakukan oleh kasir saat pelanggan akan melakukan pembayaran dengan tagihan sesuai denga napa yang dibeli kemudian data akan masuk kedalam database yang kemudian data akan diolah menjadi sebuah laporan-laporan yang nantinya akan diserahkan kepada owner sebagai bentuk pelaporan kegiatan bisnis yang 
dilakukan baik perhari, pertanggal sampai dengan pertahun dan terdapat juga sebuah angka dari hasil perhitungan pendapat yang diraih perusahaan saat pilih periode tanggal.

Perangkat lunak dari hasil penelitian ini menggunakan platform visual basic.net dengan penggunaan Bahasa basic atau bahasa $C$ yang kemudian di modulkan kedalam file .exe sehingga perangkat manapun akan dapat digunakan saat file tersebut di alokasikan ke komputer lain.

\section{Analisa kebutuhan}

Tahap pertama yang dapat dilakukan yaitu Analisa kebutuhan bagi para pengguna terhadap perangkat lunak yang akan digunakan dalam menjalan proses bisnisnya di Toko FoodPanda Bekasi. Berikut analisa kebutuhan pengguna pada Tabel 1. Berdasarkan pada hak akses terhadap perangkat lunak:

Tabel 1. Kebutuhan Pengguna

\begin{tabular}{|c|c|c|}
\hline Ne & Pengguna & Kebutuhan \\
\hline \multirow[t]{35}{*}{1} & \multirow[t]{35}{*}{ Administrator } & Admin dapat menambah admin \\
\hline & & Admin dapat menambah pegawai \\
\hline & & Admin dapat menambah data menu makanan dan minuman \\
\hline & & Admin dapat menambah data meja \\
\hline & & Admin dapat menambah data transaksi pembayaran \\
\hline & & Admin dapat menambah modul penggunaan software \\
\hline & & Admin dapat menambah fitur \\
\hline & & Admin dapat menambah gambar \\
\hline & & Admin dapat menambah profil perusahaan \\
\hline & & Admin dapat melihat laporan \\
\hline & & Admin dapat mengecek data admin \\
\hline & & Admin dapat melihat data pengguna \\
\hline & & Admin dapat melihat data pegawai \\
\hline & & Admin dapat melihat data meja \\
\hline & & Admin dapat melihat data transaksi pembayaran \\
\hline & & Admin dapat melihat laporan \\
\hline & & Admin dapat mengganti password pengguna \\
\hline & & Admin dapat melihat data makanan dan minuman \\
\hline & & Admin dapat melihat laporan master data \\
\hline & & Admin dapat mengupdate data admin \\
\hline & & Admin dapat mengupdate data pegawai \\
\hline & & Admin dapat mengupdate datamenu makanan dan minuman \\
\hline & & Admin dapat mengupdate profile \\
\hline & & Admin dapat mengupdate data meja \\
\hline & & Admin dapat mengupdate user login \\
\hline & & Admin dapat mengupdate data gambar \\
\hline & & Admin dapat mengupdate data fitur \\
\hline & & Admin dapat manghapus data admin \\
\hline & & Admin dapat manghapus data pegawai \\
\hline & & Admin dapat manghapus data makanan dan minuman \\
\hline & & Admin dapat manghapus dataprofile \\
\hline & & Admin dapat manghapus data user login \\
\hline & & Admin dapat manghapus data modul pengguna sistem \\
\hline & & Admin dapat mencetak laporan transaksi \\
\hline & & Admin dapat mencetak laporan data master \\
\hline \multirow[t]{2}{*}{2} & \multirow[t]{2}{*}{ Kasir } & Kasir dapat melakukan transaksi pembayaran \\
\hline & & Kasir dapat melakukan cetak laporan transaksi \\
\hline
\end{tabular}

Sumber: Penelitian (2020)

Berdasarkan dari table 1. Tentang kebutuhan akan perencanaan perangkat yang akan diusulkan bahwa terdapat dua pengguna yaitu admin dan kasir. Admin memiliki akses dngan penuh sedangkan kasir hanya dapat melakukan transaksi dan cetak laporan saja.

Desain

Pada tahap desain pada penelitian ini membuat desain database yang nantinya dapat di realisasikan terhadap usulan perancangan perangkat lunak. Berikut ini adalah database yang didesain hasil dari Analisa kebutuhan pada perancangan perangkat lunak Kasir FoodPanda: a. Tabel User, tabel pada database bertujuan untuk menyimpan data pengguna atas pemberian berupa hak akses seperti administrator atau admin pegawai biasa dan kasir. b. Tabel Pegawai, transaksi penyimpan dan pengolahan data pegawai terdapt dalam tabel pegawai dengan data pelanggan yang memesan makanan dan atau minuman akan tersimpan dalam tabel 
pemesanan tersebut kemudian di relasikan ke tabel pembayaran nantinya. e.Tabel Makanan dan Minuman, pengolahan data master makanan dan minuman serta data-data lainnya contoh: harga, stok, deskripsi menu makanan dan minuman. f.Tabel login, pemberian hak akses oleh admin akan digunakan saat penggunan masuk kedalam sistem, tidak semua pegawai dapat mengakses sistem atau aplikasi ini selain admin dan kasir. g.Tabel pembayaran, seleuruh transaksi pembayaran pelanggan akan dimasukan kedalam tabel pembayaran dengan perincian tagihan sesuai dengan menu yang dipesan.

\section{Implementasi Program}

Pada tahap implementasi program akan menjelaskan terkait perancangan antar muka yaitu tampilan halaman atau form yang terdapat dalam aplikasi saat mengolah data. Berikut tampilan-tampilan beserta penjelasannya.

\section{Halaman Login}

Halaman login merupakan halaman yang pertama dikunjungi pada aplikasi kasir ini. Halaman memuat dua textfield username dan password dan terdapat dua button masuk dan batal. Selayaknya seperti halaman login seperti pada umumnya memuat dua kata kunci baik username dan password atau email dan password ataupun hanya passwordnya dan semua itu tergantung kepada perusahaan. Toko FoodPand memilih untuk username dan password. Prosedurnya pengguna baik admin maupun kasir harap mengisi data username dan password yang sudah didaftarkan sebelumnya sebelum memulai aktifitas dalam aplikasi. Halaman login ini dibuat untuk menghindari dari anonymous dapat mengakses dan merusak data pada aplikasi sehingga data sudah tidak valid dan hasilnya pun tidak akan baik atau juga kecurangan bisa juga terjadi dari orang lain yang mengakses aplikasi dan mengubah susuan data sehingga saat laporan hasilnya berbeda atau tidak sesuai.

Pada saat pengguna melakukan login dan masuk ke aplikasi kasir sebelumnya sudah di validasi sesuai ranah kegiatannya dan tidak bisa mengakses selain yang sudah di berikan oleh sistem. Salah satu contohnya adalah Kasir tidak dapat mengakses atau melakukan pengolahan data master makanan dan minuman kecuali admin dan admin memegang full control dalam pengolahan disetiap kegiatan pada aplikasi dan kasir hanya dapat melakukan dua hal yaitu taransaksi pembayaran dan cetak laporan selain itu tidak bisa.

\section{Halaman Menu Utama}

Tampilan setelah login berhasil masuk dan akses aplikasi selanjutnya adalah tampilah halaman menu utama. Tampilan tersebut memilki beberapa fitur fungsi diatasnya dengan masing-masing fungsi serta pekerjaannya. Menu Utama ini dirancang untuk memberikan kemudian pengguna dalam mengakses atau memilih fitur tergantur kepada instruksi kerja di masing-masing bagian. Berikut gambar 2. tampilan Menu Utama dari aplikasi kasir penjualan FoodPanda.

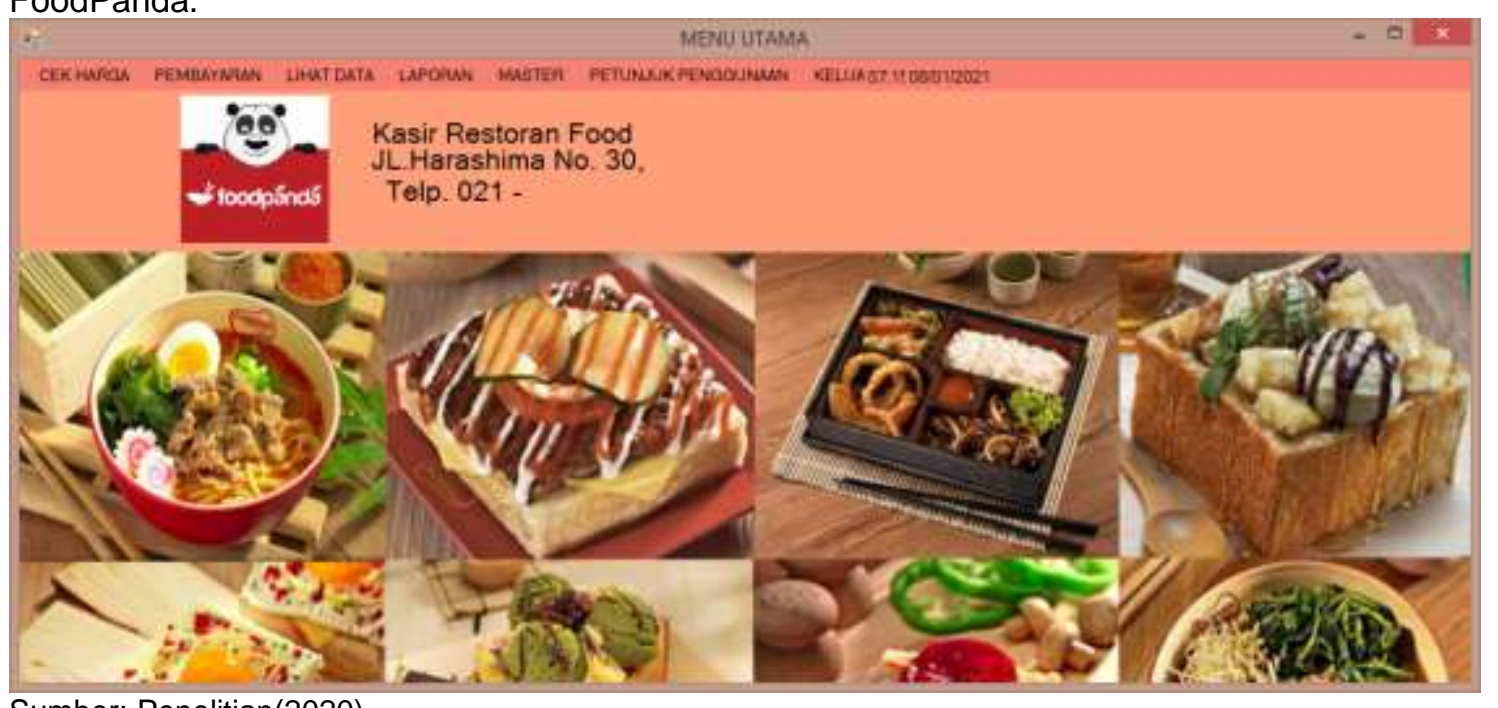

Sumber: Penelitian(2020)

Gambar 2. Tampilan Menu Utama 
Berdasarkan dari gambar 2. yaitu tampilan menu utama terdapat fitur cek harga, pembayaran lihat data, laporan, master, petunjuk penggunaan serta fitur keluar.

\section{Halaman Cek Harga}

Di halaman ini terdapat list harga dari setiap makanan dan minuman yang telah tersedia pada toko FoodPanda. Halaman ini berfungsi bagi kasir yang ingin melihat daftar harga baik manakan maupun minuman saat pelanggan bertanya. Pada halaman ini admin dapat mengolah data harga jika memang terjadi kesalah dalam penginputan serta menu makanan dan minuman sudah tidak lagi disediakan oleh FoodPanda baik sudah ada maupun belum tersedia.

\section{Halaman Pembayaran}

Dalam halaman pembayaran berisikan semua data transaksi yang dilakukan oleh kasir untuk pembayaran pembelian makanan dan atau minuman yang pelanggan telah beli. Informasi pembelian makanan dan atau minuman serta harga dari setiap makanan dan minuman kemudian pembelian dengan jumlah yang nantinya akan dihitung semua menjadi sebuah tagihan yang akan dibayar oleh pelanggan. Berikut gambar 3. halaman transaksi pembayaran yang dilakukan oleh kasih kepada pelanggan.

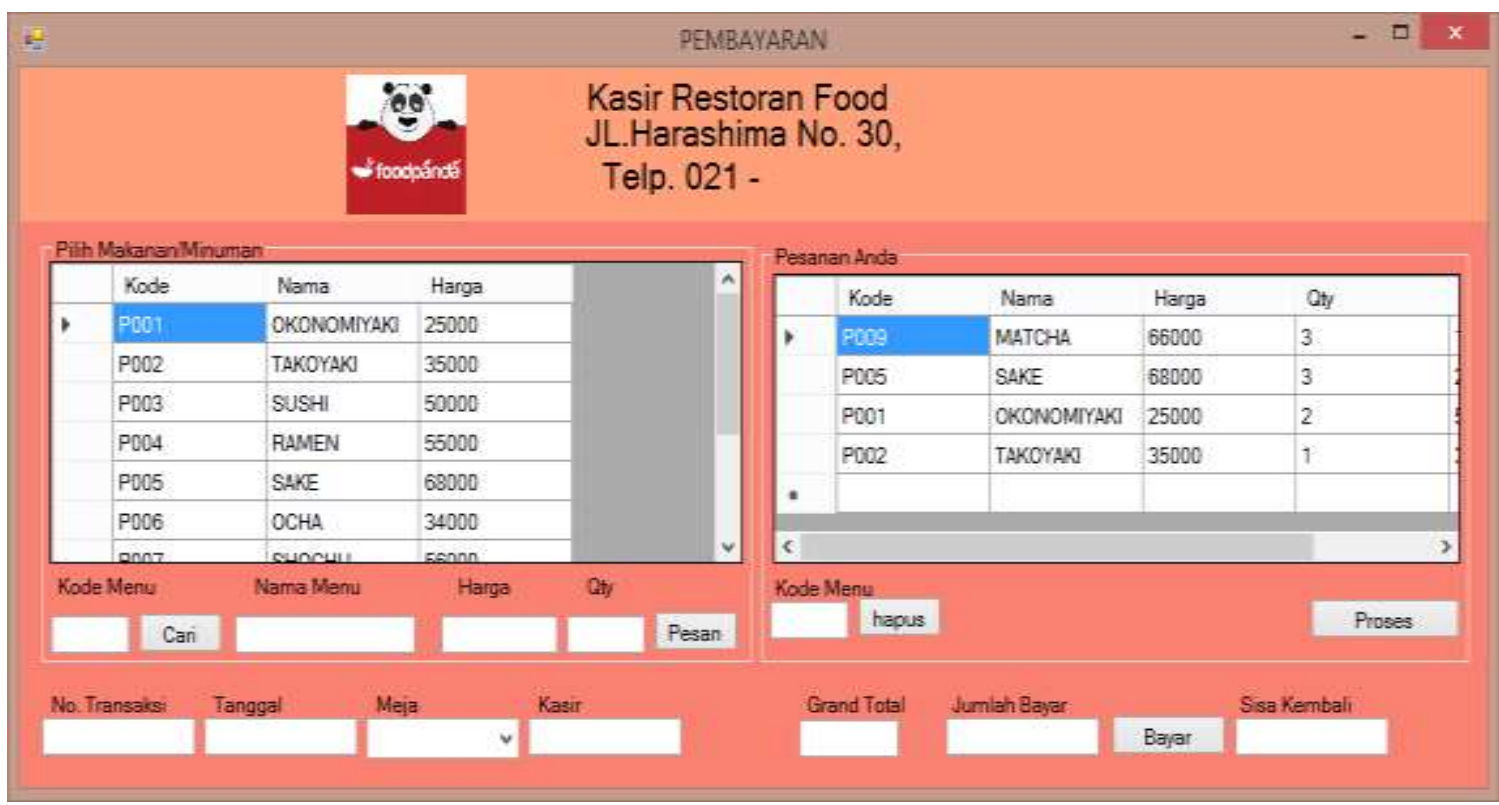

Sumber: Penelitian(2020)

Gambar 3. Halaman Transaksi Pembayaran

Berdasarkan dari gambar 3. Kasir akan mencari makanan atau minuman berdasarkan kode tersebut sehingga kasir akan mengetahui harga dan setiap makanan dan minuman yang dibeli atau dipesan oleh pelanggan dengan cara kasir akan mengklik dari list makanan dan minuman sesuai dengan pembelian oleh pelanggan dan kasir akan memberikan jumlah beli sesuai dengan keinginan pelanggan kemudian secara sistem akan tampil harga yang akan menjadi tagihan oleh pelanggan untuk dibayarkan kemudian terdapat tiga kondisi saat melakukan pembayaran, apabila pembayaran yang dibayarkan oleh pelanggan jumlahnya sama dengan tagihan oleh sistem maka sisa kembali akan bernilai nol (0) dan apabila pembayarannya lebih dari jumlah tagihan maka akan muncul sisa dari uang pelanggan yang sudah dibayarkan dan juga jika pembayarannya kurang dari jumlah tagihan yang tertera maka secara sistem akan menolak pembayar tersebut dengan memunculkan sebuah pesan yang berisikan "Mohon Maaf Pembayaran Anda Kurang Dari Jumlah Tagihan" selanjutnya selain pembayarannya kurang dari jumlah tagihan akan otomatis mengeluarkan struk pembayaran sebagai bukti pelunasan pembelian makanan dan atau minuman di Toko FoodPanda dan 
diberikan kepada pelanggan oleh kasir bila ada sisa pembayaran maka akan diberikan juga sisanya tersebut.

\section{Halaman Lihat Data}

Pada halaman lihat data admin akan melakukan pengecekan data dari semua file master seperti data pegawai, pengguna, makanan dan minuman serta meja.

\section{Halaman Laporan}

Pada halaman laporan ini tentu menjadi perhatian bagi Toko terutama bagi pemilik toko dalam melakukan perhitungan laba dan rugi di setiap harinya. Fitur laporan ini berisikan laporan master data pegawai, makanan, minuman, serta pegawai dan juga laporan dari setiap penjualan makanan dan minuman darisetiap pelanggan yag berkunjung dan makan di Toko FoodPanda ini. Kasir akan mencetak semua laporan baik perhari maupun perbulan kemudian dilaporkan kepada pemilki Toko untuk di lakukan pengecekan ulang apakah ada kesalahan data.

\section{Halaman Panduan penggunaan Aplikasi}

Panduan memang penting untuk pengguna khususnya bagi pegawai Toko yang awam akan teknologi dengan fitur ini, pegawai akan terasa sangat membantu dalam melakukan kegiatan dalam aplikasi Toko FoodPanda. selain itu pengguna sistem dapat membaca secara berulang-ulang sehingga pengguna akan mahir dalam menggunakan aplikasi ini dan semakin baik luaran yang dihasilkan dari aplikasi ini. Berikut gambar 4. tentang panduan penggunaan aplikasi kasir penjualan restoran FoodPanda Bekasi.

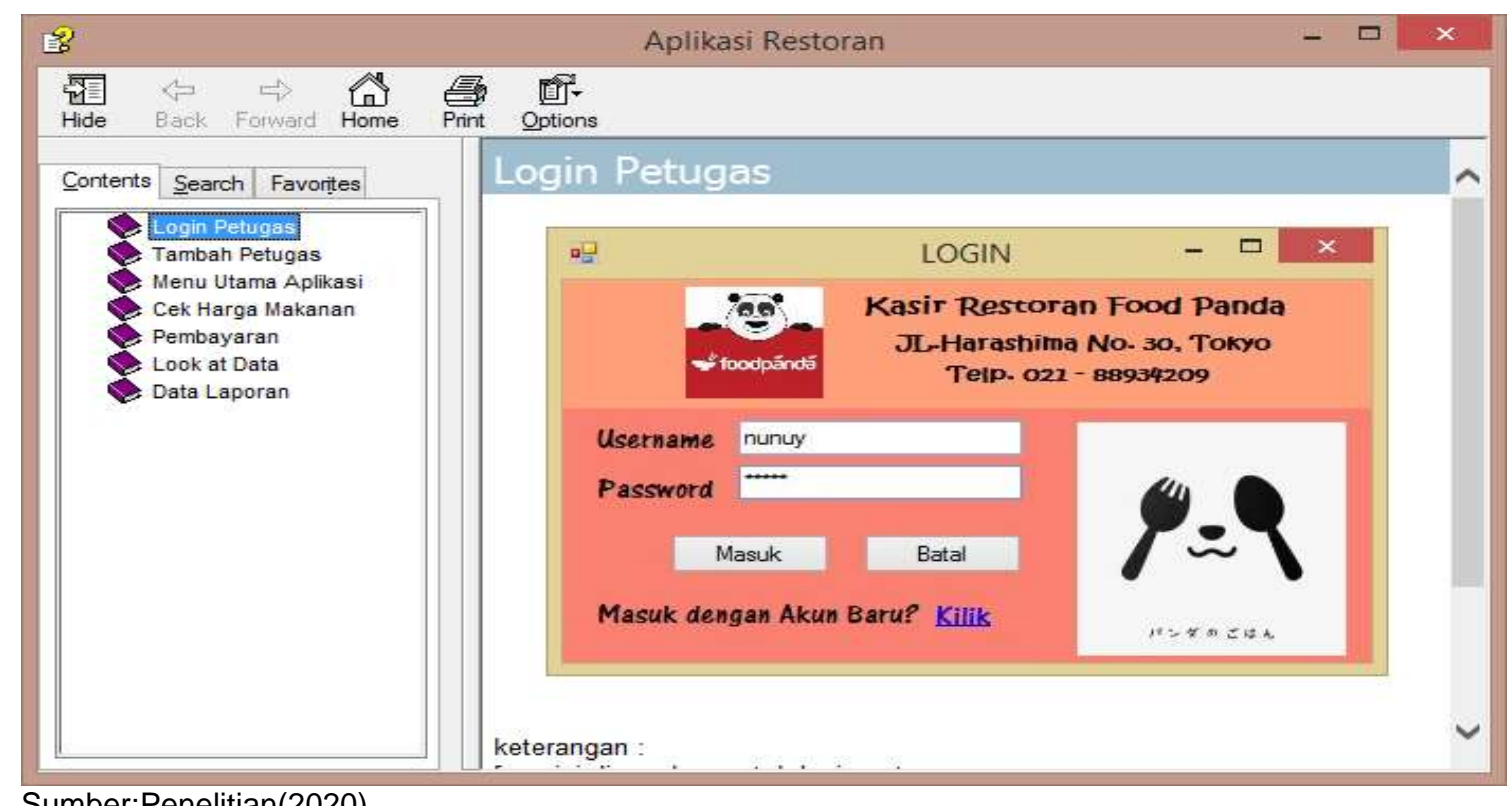

Sumber:Penelitian(2020)

Gambar 4. Panduan Penggunaan Aplikasi

Berdasarkan dari Gambar 4. Tentang panduan penggunaan aplikasi, pengguna khususnya akan sangat membantu dalam melakukan kegiatan akses aplikasi ini terutama terhindarnya dari kesalahan-kesalahan dari berbagai sumber yang dapat merusak data Toko.

\section{Pengujian Program}

Pengujian terhadap hasil perancangan aplikasi penelitian ini yaitu tahap dimana beberapa fitur aplikasi kasir penjualan pada Toko FoodPanda akan di uji dengan menggunakan metode Black Box guna aplikasi ini dapat memberikan hasil yang lebih baik dan mengetahui dari setiap Langkah-langkah jalannya aplikasi oleh pengguna, selain itu pengujian ini dapat berdampak baik terhadap kegiatan pengembangan dan evalusi sampai aplikasi memiliki nilai yang bermanfaat bagi Toko 


\section{Pengujian Black Box Fungsi Login}

Berikut proses pengujian menggunakan metode Black Box yang aka diuji pada fungsi fitur login pengguna seperti keterangan pada tabel berikut ini.

Tabel 2. Pengujian BlackBox pada Form Login

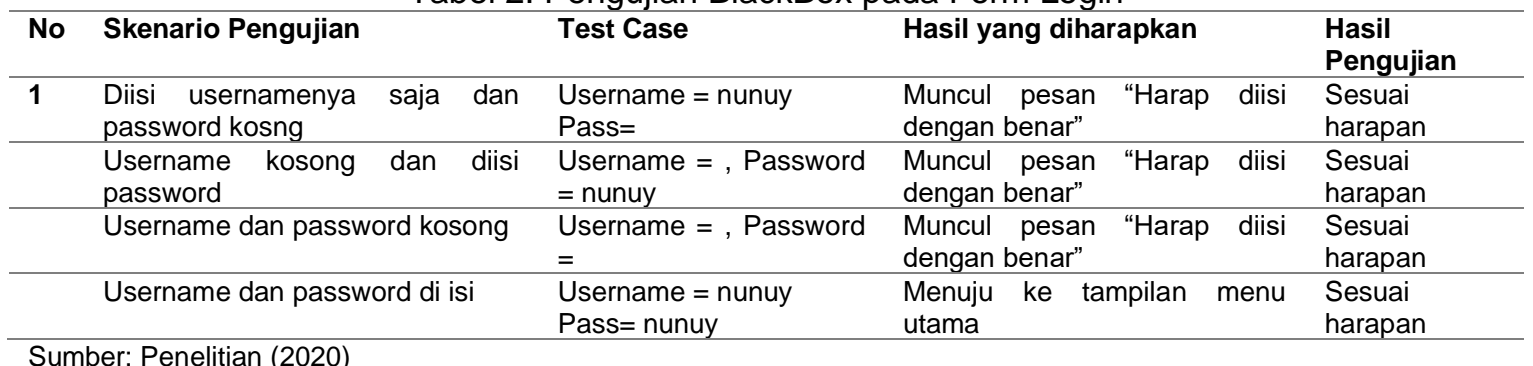

Berdasarkan dari hasil pengujian dengan metode BlackBox pada halaman login menunjukan validasi pengguna yang akan masuk atau mengakses aplikasi sudah sesuai dengan harapan dari Toko FoodPanda. Dengan ini pengujian pada halaman login akan membuat keamanan aplikasi menjadi lebih baik dan terhidar dari pegawai yang ingin masuk kedalam aplikasi tersebut.

\section{Kesimpulan}

Sistem berjalan yang diterapkan oleh toko FoodPanda masih bersifat konvensional yaitu semua kegiatan dari pemesanan, penyidangan makanan dan minuman, pembayaran serta pelaporan menggunakan buku kertas sehingga sangat rentan terhadap kerusakan atau kehilangan data perusahaan. Perancangan sistem yang diusulkan untuk toko FoodPanda dalam membantu menangani proses bisnis mulai dari pemesanan, pembayaran dan pelaporan dan penyimpanan secara teknologi ke dalam database untuk data master seperti data pegawai, data pengguna, data menu makanan dan minuman hingga data pelaporan.

\section{Referensi}

[1] D. W. Kuncoro, bambang eka Purnama, and indah uly Wardati, "Sistem Kasir Dan Pendataan Stok Barang Pada Tata Distro Pacitan," J. Speed, vol. 7, no. 1, pp. 40-46, 2015.

[2] Y. D. Wijaya and M. W. Astuti, "Sistem Informasi Penjualan Tiket Wisata Berbasis Web Menggunakan Metode Waterfall," Pros. Semin. Nas. Teknol. Inf. dan Komun., vol. 2, no. 1, pp. 273-276, 2019.

[3] D. Setiyadi, Sistem Basis Data Dan SQL. Jakarta: Mitra Wacana Media, 2020.

[4] A. Jamal and L. Yulianto, "Rancang Bangun Sistem Informasi Aplikasi Kasir Menggunakan Barcode Reader Pada Toko Dan Jasa Widodo Computer Ngadirojo Kabupaten Pacitan," J. Speed - Sentra Penelit. Eng. dan Edukasi, vol. 5, no. 3, pp. 4554, 2013.

[5] S. C. Cahyodi and R. W. Arifin, "Sistem Informasi Point Of Sales Berbasis Web Pada Colony Amaranta Bekasi," Inf. Syst. Educ. Prof., vol. 1, no. 2, pp. 189-204, 2017.

[6] R. Hidayat, S. Marlina, and L. D. Utami, "Perancangan Sistem Informasi Penjualan Barang Handmade Berbasis Website Dengan Metode Waterfall," Simnasiptek, pp. 176183, 2017.

[7] M. Y. Putra and J. Shadiq, "Sistem Informasi Penerimaan Siswa Baru pada SMK Bekasi Berbasis Website," Bina Insa. Ict J., vol. 7, no. 1, pp. 43-52, 2020.

[8] I. D. L. - AMIK BSI Purwokerto and F. R. - AMIK BSI Purwokerto, "Sistem Informasi Penjualan Merchandise Berbasis Web Pada PT Come Indonusa Dengan Metode Waterfall," Evolusi J. Sains dan Manaj., vol. 6, no. 2, pp. 91-97, 2018.

[9] G. W. Sasmito, "Penerapan Metode Waterfall Pada Desain Sistem Informasi Geografis Industri Kabupaten Tegal," J. Inform. Pengemb. IT, vol. 2, no. 1, pp. 6-12, 2017.

[10] N. Purwanti and I. D. Fatmaningtyas, "Sistem Informasi Pengolahan Data Anak dan Guru pada Yayasan Rumah Qur' an Violet Indonesia Berbasis Website," vol. 5, no. 1, pp. 53-62, 2020.

[11] R. Pramudita, "Pengujian Black Box pada Aplikasi Ecampus Menggunakan Metode Equivalence Partitioning," Informatics Educ. Prof., vol. 3, no. 2, p. 100, 2020. 